\title{
Interconnection of Hybrid Power System to Grid \& Enhance Power Quality Features in DG System using Multilevel STATCOM
}

\author{
Sk Shabana, L Shanmukha Rao
}

\begin{abstract}
The distributed generation scheme with integration of renewable energy sources furnishes the feasible solution to acquire the stable power demand in grid-connected system under sudden load interruptions. Over the various compensation devices, the highly recognized multi-purpose Static Compensator is integrated to grid for attaining enhanced power quality features. A co-generation based grid-integrated renewable sources are used but, the output of these sources are maintained un-constant due to presence of variable source. In this paper, a novel current controller was developed to maintain output of co-generation system as constant and achieve the load demand continuously. But, this scheme has two major disadvantages, primary one is current controller prerequisites the traditional PI controller, which is controlled by intelligent based Fuzzy-Logic controller that is adopted. The second is, the regular 3-level voltage-source inverter is used in STATCOM which has square-wave output voltage requires high range of filter units, more common-mode voltage, high dv/dt stress, more switching losses, low efficiency, so on. These issues are counteracted by utilizing multilevel inverter with attractive modulation scheme. The performance evaluation of proposed Multilevel Inverter based STATCOM is verified by traditional PI and proposed Fuzzy-Logic current controller by using MATLAB/SIMULINK tool and results are conferred with comparisons.
\end{abstract}

Keywords: Advanced Current Controller, Fuzzy-Logic Controller, Multi-Level Inverter, Multi-Purpose Static Compensator, PI Controller, Power Quality Improvement.

\section{INTRODUCTION}

The growth of global population, increased utilization of power-electronic devices which consumes electrical energy and demand of electrical energy has been extended to unpredicted levels. In present scenario, the electrical energy has been diminished due to limited fossil fuels, social, environmental and geographical issues [1], [2]. To fulfill these issues, several attempts have been constituted to meet the energy demand natively through Distributed Generators

Revised Manuscript Received on February 05, 2020.

* Correspondence Author

Sk Shabana,UG Student, EEE department, Kallam Haranadhareddy Institute of Technology, Guntur, Andhra Pradesh, INDIA. Name of the affiliated College or University/Industry, City, Country. Shabanashaik1999@gmail.com

L Shanmukha Rao, Professor/EEE department, Kallam Haranadhareddy Institute of Technology, Guntur, Andhra Pradesh, INDIA, lsrlingineni@yahoo.co.in

(C) The Authors. Published by Blue Eyes Intelligence Engineering and Sciences Publication (BEIESP). This is an open access article under the CC BY-NC-ND license (http://creativecommons.org/licenses/by-nc-nd/4.0/)
(DG's) [3]. The incredible establishment of DG scheme provides the greater energy demand, clean energy, sustain the stable real-power exchanging under sudden-load variations with the help of Renewable Energy Sources (RES) [4], [5]. Renewable sources like Wind-Turbine (WT), Fuel-Cell (FC) and Solar-Photovoltaic (SPV) systems are directly interfaced to grid system by employing power-conditioner systems. Harnessing the electric energy from SPV system furnishes the clean energy, extensive nature in present climatic situations, pollution free, long life and greater efficiency characteristics that are the key merits of SPV system.

Over the single sourced DG scheme, two or more RES's are integrated as hybrid formation called as co-generation system for maintaining continuous load demand eliminate the sudden changes, etc. Generally, the output of SPV is very low in nature and are integrated to PCC/load with the accomplishment of high-voltage gain DC-DC boost converter and DC-AC Voltage-Source Inverter (VSI) is utilized with attractive control objective. Many industrial and domestic appliances utilize the power-electronic converters which lead to poor power quality standards in grid connected system. Severe economic technical impacts are greatly experienced because of current and/or voltage imperfections at PCC level [6]. These concerns are frequently appeared due to presence of non-linear loading, faulty conditions, sudden-loading conditions, etc.

The custom-power technology is introduced in [7], which adopts the group of apparatus furnishes the enhanced PQ features over the passive compensation methods. In former days, the traditional passive compensation schemes are accessible for PQ enhancement consisting of passive filter modules, which are connected to PCC either shunt formation or series formation. Several de-merits are highlighted in [8], such as fixed compensation scheme, low dynamic response, massive size, resonance issues etc. Multilevel Inverter (MLI) topologies have been broadly accepted for high-power medium voltage applications and have superior performance over the traditional 2-level inverters. Generally, MLI involves utilization of higher range of active semi-conductor switches to fulfill the power-transformation based on very small voltage steps. Several advantages are achieved over the formal approaches such as, generation of good qualitative RMS waveforms, low harmonic content, minimum $\mathrm{dv} / \mathrm{dt}$ stress, low EMI compatibility issues, etc. The MLI's are framed as series connected semiconductor switch which enables high-voltage operations and produces the staircase output voltage and/or current waveform. 


\section{Interconnection of Hybrid Power System to Grid \& Enhance Power Quality Features in DG System using Multilevel STATCOM}

The proposed multi-level multi-purpose Static Compensator (MLI-STATCOM) reduces the necessity of additional DG-VSI topology and minimizes the overall compensation costs which increase the power demand capability. The primary task of proposed MLI-STATCOM is harmonic elimination, reactive power improvement, power-factor correction, unbalanced load, and compensates all current related issues [9]. The secondary task of MLI-STATCOM is integration of co-generation system into local load as DG-inverter for regulating the sudden load demand, etc. In this paper, CO-generation based solar PV and Wind Conversion scheme is used as secondary source of grid-connected DG system integrated to PCC level. But the output of these two source are varied with respect to changes in wind flow and light intensity of SPV arrays which affects the output of DG-VSI and the DC-link voltage as un-constant, may create un-balanced grid voltages. To eliminate the issues coming from PI controller, a new intelligent based Fuzzy-Logic Controller is pre-requisite for enhancing better performance of multi-purpose MLI-STATCOM with improved PQ compensation characteristics with a good stability index. A critical evaluation of SPV-Wind CO-generation scheme based MLI-STATCOM is validated in both PQ enhancement and DG integration scheme by using MATLAB/SIMULINK tool and confers the simulation results with appropriate comparisons.

\section{PROPOSED DIODE-CLAMPED MULTI-LEVEL STATCOM}

The MLI topologies are generally categorized as Diode-Clamped Multi-level Inverter (DC-MLI) type, Flying Capacitor Multi-level Inverter (FC-MLI) type and Cascade H-Bridge Multi-level Inverter (CHB-MLI) type (covering both Symmetrical and Non-Symmetrical versions). Over the several MLI topologies, CHB-MLI is highly recognized for many applications because of greater-modular design, no need of auxiliary components, etc. The CHB-MLI have several disadvantages like, it is limited to certain range of levels due to high number of switches and DC sources which are required for generating increased output voltage levels [10]. When it is operated for higher number of voltage levels, it can produce high switch stress pertains to more switching losses and decreasing the over-all efficiency. Thus DCMLI is suitable and preferable in STATCOM for compensating all voltage and current related issues and also DG integration scheme under sudden-load changes [11].

The MLI-STATCOM is mainly integrated to grid-connected systems to improve PQ features and it comprises of three-phase Diode-Clamped MLI module, reference current generator, gate-drive circuit, DC-link capacitor, sensing elements, second-order LC filters, etc. The DCMLI-STATCOM is acted as active compensation device operated in a current control mode for harmonic elimination coming from non-linear loads and also utilized as integrated converter in DG operation [10]. In this scheme grid is supporting the dual non-linear loads, at initial stage load-1 is connected and the second load is connected suddenly at a time of $0.3 \mathrm{sec}$. Due to this sudden switching of additional load apparatus, the requirement of load current is extracted from the grid which affects the PCC and requirement of load power was increased. During DG operation DCMLI is operated in voltage-controlled mode to provide active-power to the load. Generally, the DG scheme requires additional source as battery energy storage system (BESS), but it requires additional charge management schemes. Over the BESS, the renewable energy plays a significant role in DG schemes and in that SPV-Wind is the major power producer as CO-generation scheme [12].

\section{A.DIODE-CLAMPED MLI TOPOLOGY}

The schematic diagram of 5-level DC-MLI topology is shown in Fig.1. It comprises of 2(n-1) switches, named as positive group switches $S_{1 a}, S_{2 a}, S_{3 a}, S_{4 a}$, and negative group switches are $\mathrm{S}_{1 \mathrm{a}}{ }^{\prime}, \mathrm{S}_{2 \mathrm{a}}{ }^{\prime}, \mathrm{S}_{3 \mathrm{a}^{\prime}}, \mathrm{S}_{4 \mathrm{a}}{ }^{\prime}$; (n-1) x (n-2) clamping diodes are $\mathrm{D}_{1 \mathrm{a}}, \mathrm{D}_{1 \mathrm{~b}}, \mathrm{D}_{2 \mathrm{a}}, \mathrm{D}_{2 \mathrm{~b}}, \mathrm{D}_{3 \mathrm{a}}, \mathrm{D}_{3 \mathrm{~b}}$ and $\mathrm{D}_{1 \mathrm{a}} \mathrm{a}^{\prime}, \mathrm{D}_{1 \mathrm{~b}}, \mathrm{D}_{2 \mathrm{a}} \mathrm{a}^{\prime}, \mathrm{D}_{2 \mathrm{~b}}$ ', $\mathrm{D}_{3 \mathrm{a}}{ }^{\prime}$, $\mathrm{D}_{36}$ ', (n-1) DC-link capacitors, without clamping capacitors.

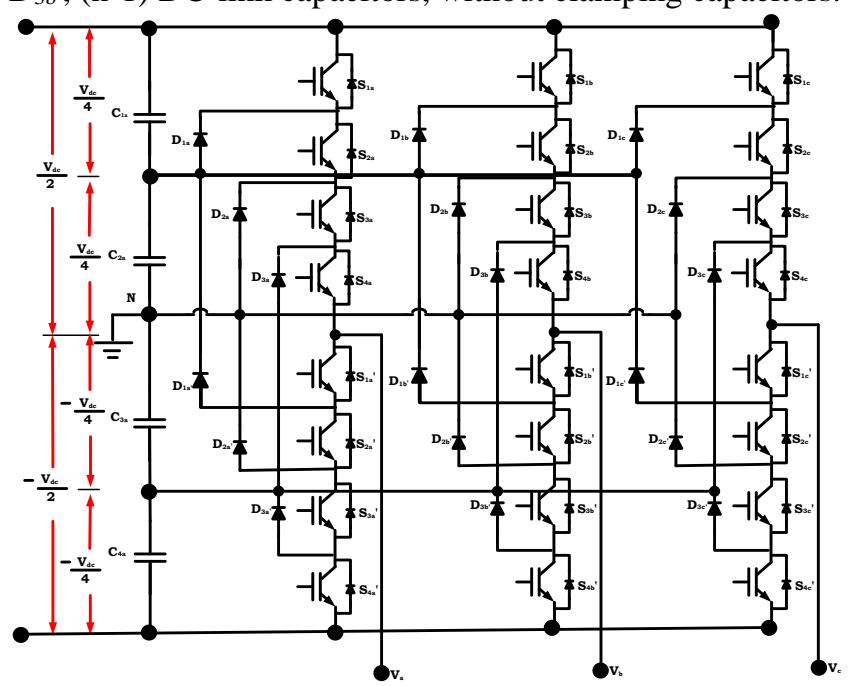

Fig.1 Schematic Diagram 5-Level DCMLI Topology

The DC-link voltage $\left(\mathrm{V}_{\mathrm{dc}}\right)$ is split into five voltage levels by utilizing four series-interfaced bulk capacitors such as, $\mathrm{C}_{1 \mathrm{a}}, \mathrm{C}_{2 \mathrm{a}}, \mathrm{C}_{3 \mathrm{a}}, \mathrm{C}_{4 \mathrm{a}}$; these are separated with a middle-point as a neutral point $(\mathrm{N})$. The output voltage $\mathrm{V}_{\mathrm{o}}$ has five voltage levels such as $\mathrm{V}_{\mathrm{dc}} / 4, \mathrm{~V}_{\mathrm{dc}} / 2,-\mathrm{V}_{\mathrm{dc}} / 4,-\mathrm{V}_{\mathrm{dc}} / 2$ and $0 \mathrm{~V}_{\mathrm{dc}}$ with respect to neutral point $\mathrm{N}$. The switching pattern of DC-MLI for switching the consequent switches is illustrated in Table.1. In that, " $\mathrm{H}$ " represents the switch-ON state and " $\mathrm{L}$ " represents the switch-OFF state.To demonstrate how 5-level stair-case voltage is synthesized, a load is connected in between the output point (Vo) and neutral point "N". In mode $A$, the upper switches $S_{2 a}, S_{3 a}, S_{4 a}$ and lower switch $S_{1 a}$ 'is conducted in positive half cycle for generation of $\mathrm{V}_{\mathrm{dc}} / 4$ at output node $\mathrm{V}_{\mathrm{o}}$. In mode $\mathrm{B}$, the upper switches $\mathrm{S}_{1 \mathrm{a}}, \mathrm{S}_{2 \mathrm{a}}, \mathrm{S}_{3 \mathrm{a}}$, $\mathrm{S}_{4 \mathrm{a}}$ are conducted in positive half cycle for generation of $\mathrm{V}_{\mathrm{dc}} / 2$ at output node $\mathrm{V}_{\mathrm{o}}$. In mode $\mathrm{C}$, the upper switches $S_{3 \mathrm{a}}$, $S_{4 a}$ and lower switches $S_{1 a}{ }^{\prime}, S_{2 a}$ are conducted for generation of $0 \mathrm{~V}_{\mathrm{dc}}$ at output node $\mathrm{V}_{\mathrm{o}}$.

Table.1 Switching Pattern of DCMLI topology

\begin{tabular}{|c|c|c|c|c|c|c|c|c|}
\hline \multirow{2}{*}{$\begin{array}{l}\text { Output } \\
\text { Voltage } \\
\text { (Vo) }\end{array}$} & \multicolumn{8}{|c|}{ Operated Switching States } \\
\hline & $S_{1 a}$ & $S_{2 a}$ & $\mathrm{~S}_{3 \mathbf{a}}$ & $S_{4 a}$ & $\mathrm{~S}_{1 \mathrm{a}^{\prime}}$ & $S_{2 a^{\prime}}$ & $\mathrm{S}_{3 \mathrm{a}^{\prime}}$ & \\
\hline$V_{\mathrm{dc}} / 4$ & $\mathrm{~L}$ & $\mathrm{H}$ & $\mathrm{H}$ & $\mathrm{H}$ & $\mathrm{H}$ & $\mathrm{L}$ & $\mathrm{L}$ & $\mathrm{L}$ \\
\hline $\mathrm{V}_{\mathrm{dd} /} / 2$ & $\mathrm{H}$ & $\mathrm{H}$ & $\mathrm{H}$ & $\mathrm{H}$ & $\mathrm{L}$ & $\mathrm{L}$ & $\mathrm{L}$ & $\mathrm{L}$ \\
\hline
\end{tabular}




\begin{tabular}{|c|c|c|c|c|c|c|c|c|}
\hline $\mathbf{0} \mathbf{V}_{\mathbf{d c}}$ & $\mathrm{L}$ & $\mathrm{L}$ & $\mathrm{H}$ & $\mathrm{H}$ & $\mathrm{H}$ & $\mathrm{H}$ & $\mathrm{L}$ & $\mathrm{L}$ \\
\hline$-\mathbf{V}_{\mathbf{d c}} / \mathbf{4}$ & $\mathrm{L}$ & $\mathrm{L}$ & $\mathrm{L}$ & $\mathrm{H}$ & $\mathrm{H}$ & $\mathrm{H}$ & $\mathrm{H}$ & $\mathrm{L}$ \\
\hline$-\mathbf{V}_{\mathbf{d d}} / \mathbf{2}$ & $\mathrm{L}$ & $\mathrm{L}$ & $\mathrm{L}$ & $\mathrm{L}$ & $\mathrm{H}$ & $\mathrm{H}$ & $\mathrm{H}$ & $\mathrm{H}$ \\
\hline
\end{tabular}

In mode $\mathrm{D}$, the upper switch $\mathrm{S}_{4 \mathrm{a}}$ and lower switch $\mathrm{S}_{1 \mathrm{a}}$, $\mathrm{S}_{2 \mathrm{a}} \mathrm{S}_{3 \mathrm{a}}{ }^{\prime}$ are conducted in negative half cycle for generation of $-\mathrm{V}_{\mathrm{dc}} / 4$ at output node $\mathrm{V}_{\mathrm{o}}$. In mode $\mathrm{E}$, all the lower switch $\mathrm{S}_{1 \mathrm{a}}$, $\mathrm{S}_{2 \mathrm{a}}{ }^{\prime}, \mathrm{S}_{3 \mathrm{a}}{ }^{\prime}, \mathrm{S}_{4 \mathrm{a}}{ }^{\prime}$ are conducted in negative half cycle for generation of $-\mathrm{V}_{\mathrm{dc}} / 2$ at output node $\mathrm{V}_{\mathrm{o}}$ with respect to furnishing of optimal switching state. The SPV-Wind is the primary source of DCMLI, commonly which is integrated to DC-link capacitor $\mathrm{C}_{\mathrm{dc}}$ by utilizing high-voltage gain DC-DC converter. This boost converter transforms the low-level SPV-Wind voltage into high-level required voltage to drive the DCMLI-STATCOM and sustains DC-link voltage $\mathrm{V}_{\mathrm{dc}}$ as constant [13]. An interfacing LC filter modules are allied to sustain the proper compensation characteristics at PCC of grid system. The performance evaluation of multi-purpose DCMLI-STATCOM is well established based on active-filtering technique immensely pre-requisite of harmonic mitigation as in-phase compensation process [14]. It supervises the injection currents at PCC level for appropriate harmonic mitigation, reactive power exchanging, power-factor improvement and active power injection by utilizing attractive reference current control scheme. The schematic diagram of proposed DCMLI-STATCOM with CO-generation scheme is illustrated in Fig.2.

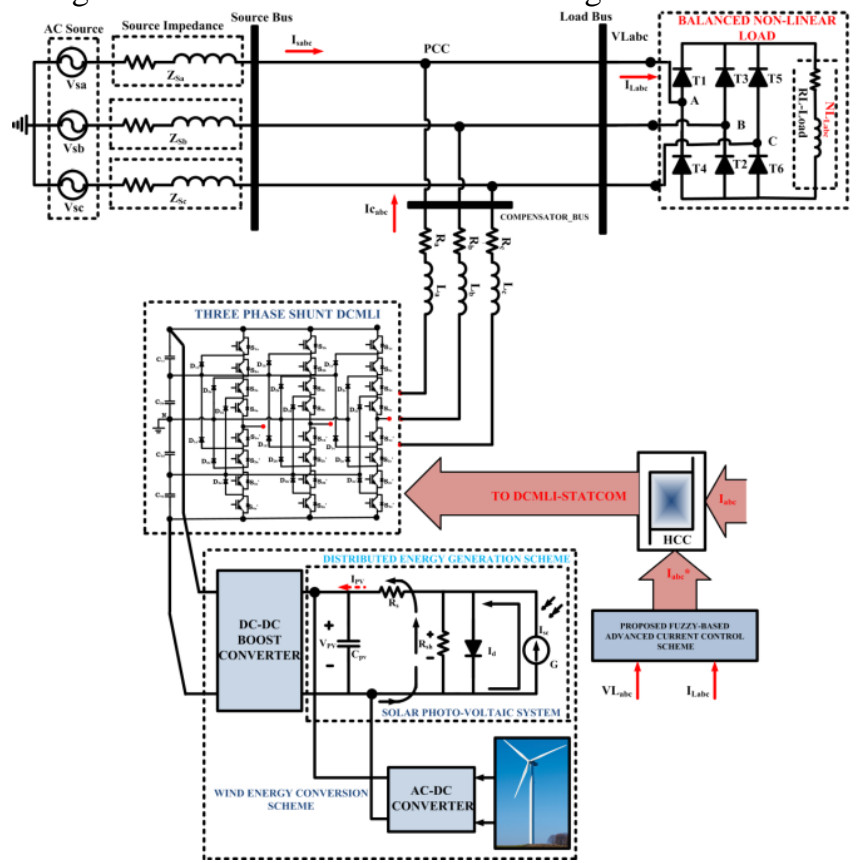

Fig.2. Schematic Diagram of Proposed Multi-Purpose DCMLI-STATCOM Driven by CO-Generation SPV-Wind System

\section{PROPOSED ADVANCED CURRENT CONTROLLER}

In this paper advanced Icos $\Phi$ controller control technique is used for generation of switching states to static compensator. Control technique of the proposed system is shown in Fig.3. In this case input current and voltage is sensed from sensor and input to Fourier and phase lock loop block respectively. Fourier block generates fundamental current magnitude and cosine displacement. Similarly phase lock loop generates active component after active component product with PI control output. This output is adding with product of fundamental current magnitude and cosine displacement and finally generates reference signal. This reference signal compared with actual source current and gives to Hysteresis Current Controller (HCC) for generation of switching states to IGBT gate terminal in static compensator circuit. According to pulse input switching devices IGBT can be operated and static compensator output can be control. In Icos $\Phi$ control techniques I is fundamental load current amplitude and $\cos \Phi$ is displacement power factor of load and their product is $\operatorname{I} \cos \Phi$ so proposed controller is named as Icos $\Phi$ controller.

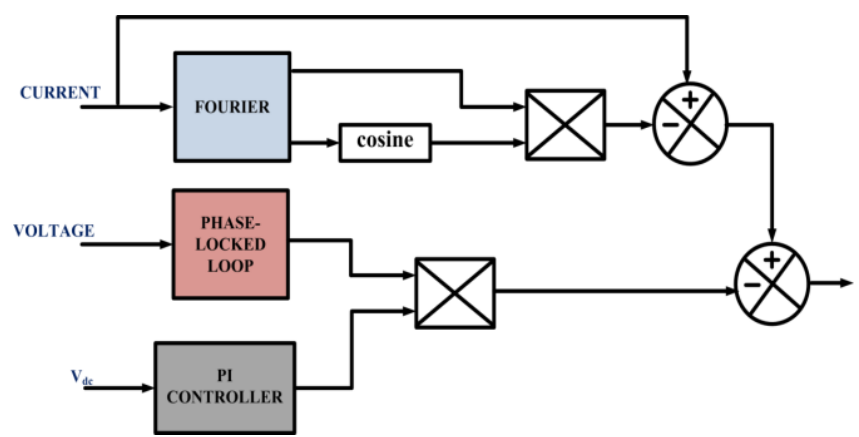

Fig.3 Block Diagram of Proposed Control Circuit

\section{A.Fuzzy-Logic Controller}

The Fuzzy-Logic (FL) controller authorize based on knowledge system which includes Fuzzy membership functions and Fuzzy rule-base to assimilate the human knowledge for getting subjective decisions. Some efforts have been developed to attain improved characteristics on system performance by integrating learning mechanism by regulating membership functions and rule-base system of the Fuzzy-controller. The heart of the Fuzzy controller is a knowledge system which comprises of information unit for providing linguistic variables and fuzzy rule base.

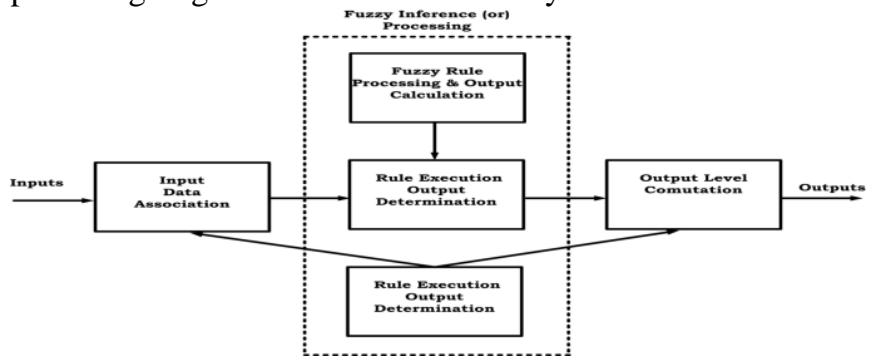

Fig.4 Fuzzy Logic Inference

The system associated with database is used to

characterize the fuzzy-rule functions and manipulation of fuzzy data in a Fuzzy-Logic controller and the heuristic rules of the knowledge which are highly influencing the controller performance. The inference mechanism decides how the fuzzy-logical operations are accomplished, and knowledge base simultaneously determines the output of fuzzy logic controller based on IF-THEN rules. The Fuzzy-Logic controller is used to furnishing the reference current signal for generation of optimal switching states to compensator based on mamdani structure. In that single FL controller is used for error regulation in DC-link controller between the actual and reference DC-link voltage in an advanced current control theory for generation of reference current signals [15]-[17].

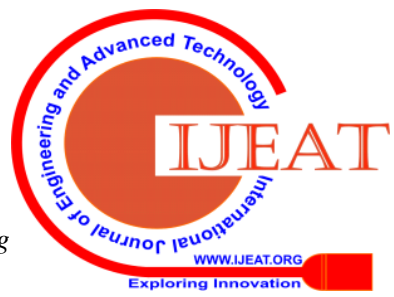




\section{Interconnection of Hybrid Power System to Grid \& Enhance Power Quality Features in DG System using Multilevel STATCOM}

The error is attained from comparison of actual and reference components in terms of current imperfections are considered as input or output for FL controller with seven linguistic variables. All the membership functions of error, change in error and output are considered as triangular functions because of simple control functions as linearity principle. These membership functions are transformed to fuzzy data by using fuzzification process for making the favorable decisions as rule-base system and provide the output signals and again re-transformed into general data by using centroid method of defuzzification process. The utilized membership functions are Zero (ZE), Positive-Large (PL), Positive-Medium (PM), Positive-Small (PS) and Negative-Large (NL), Negative -Medium (NM), Negative -Small (NS), respectively as depicted in Fig.5 and the rule-base is depicted in Table.2. The FL controllers generates the reference current signals and send to gate-drive circuitry for generation of optimal switching states to MF-STATCOM for achieving good compensation features.

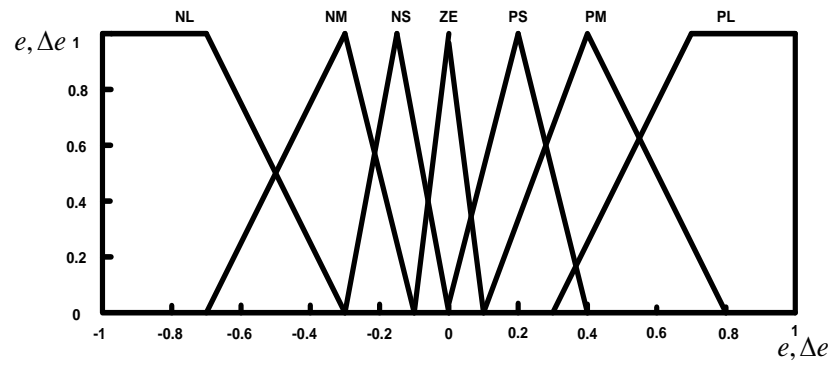

Fig. 5 Membership Functions of FLC

Table.2Rule-Base of FLC

\begin{tabular}{|c|c|c|c|c|c|c|c|}
\hline $\mathbf{e}$ & & & & & & & \\
\hline $\mathbf{N L}$ & $\mathbf{N L}$ & NM & NS & ZE & PS & PM & PL \\
\hline NM & NL & NL & NL & NL & NM & NS & ZE \\
\hline NS & NL & NL & NM & NS & ZE & PS & PS \\
\hline ZE & NL & NM & NS & ZE & PS & PM & PL \\
\hline PS & NM & NS & ZE & PS & PM & PL & PL \\
\hline PM & NS & ZE & PS & PM & PL & PL & PL \\
\hline PL & ZE & NM & NS & EZ & PS & PM & PL \\
\hline
\end{tabular}

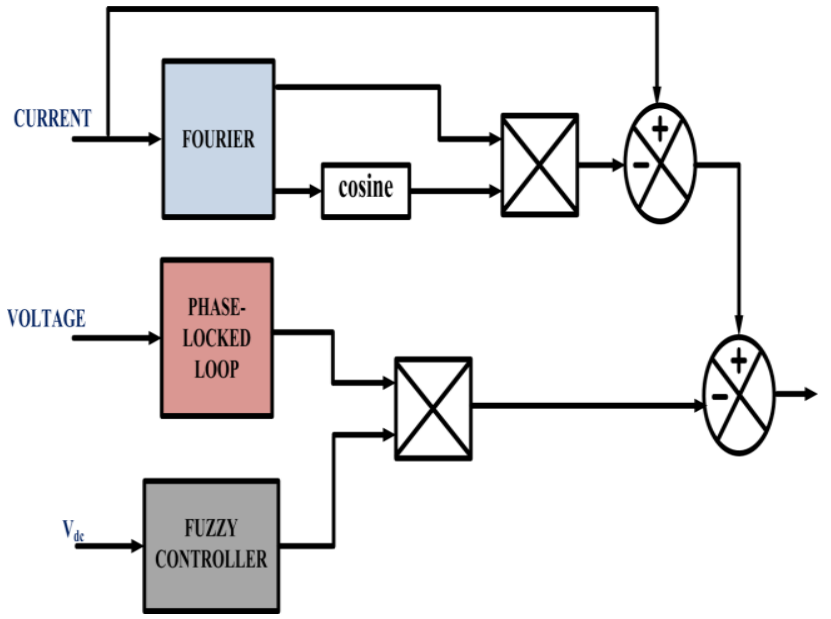

Fig.6 Block Diagram of Proposed Fuzzy Control Circuit

\section{CO-GENERATION SCHEME}

Two or more renewable energy sources are connected to a grid connected system as hybrid or CO-generation electrical power system. In this paper dual SPV-Wind energy sources are used for providing energy to the loads under sudden interruptions coming from additional load with the help of DCMLI-STATCOM.

\section{A.Solar PV System}

The solar PV energy is primary energy source in CO-generation system and it relies on the photo-electric effect to produce the electrical energy [4]. In the dark circumstances of the PV cell is akin of normal diode, when the sun-light energy is higher than the semiconductor energy gap which provides the cell electrons becomes free and existed current travels through external circuitry. As PV cell have low voltage and more fragile, formed as modules and securing with an enclosed metallic case. Based on the requirement power levels, the PV cells are integrated as series and/or parallel to form as solar PV-array. The mathematical model of the PV cell is extracted by single diode model as depicted in Fig.7. The outcome of the PV cell resulted based on the physical attraction of the PV cell is relating with the $I_{s v}, I_{p h v}, R_{s v}$ from the irradiation and temperature over the other.

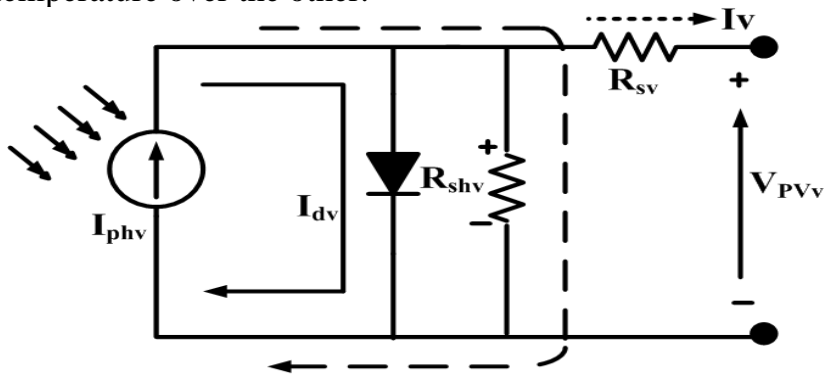

Fig.7 Mathematical model of Solar PV System

$$
I v=I_{p h v}-\left(I_{s v}\left[\exp q \frac{V_{P V v}+R_{s v} I v}{N K T}\right]-1\right)-\left[\frac{V_{P V v}+R_{s v} I v}{R_{s h v}}\right]
$$

The Eqn.1 illustrates the current equation of PV cell, Where,

$I_{p h v}$ - Photovoltaic current in amps (A)

$I_{s v}$ - Diode's reverse saturation current in amps (A)

$q$ - Electron charge

$V_{P V v}$ - Terminal voltage of the diode in volts (V)

$K$ - Boltzmann's constant value

$T$ - Junction wise temperature

$N$ - Ideality index factor of diode

$R_{\text {shv }}$ - Shunt resistance of PV cell in ohms $(\Omega)$

$R_{S V}$-Series resistance of PV cell in ohms $(\Omega)$

\section{B. Wind Energy System}

The Wind-Energy scheme acts as secondary source and it comprises of induction generator, due to variable speeds and no need of any additional field excitation circuits. The available wind energy is

$$
P_{w}=\frac{1}{2} \rho A V_{w}^{3}
$$

Where, $\rho$ is air-density, A is area of turbine, $\mathrm{V}_{\mathrm{w}}$ is wind speed and impossible to extract the kinetic energy of wind, its 
extraction in terms of fraction of power in wind known as,

$$
\begin{gathered}
P_{m}=C_{p} P_{w} \\
P_{m}=C_{p} \frac{1}{2} \rho A V_{w}^{3}
\end{gathered}
$$

Then $A=\pi R^{2}$

\section{MATLAB/SIMULINK RESULTS}

The performance of proposed MF-STATCOM is verified under traditional PI and proposed Fuzzy-Logic control functions by using MATLAB/SIMULINK tool with operating specifications as depicted in Table.3.

Table.3 Operational Parameters of Proposed DCMLI-STATCOM

\begin{tabular}{|c|c|}
\hline Parameters & Values \\
\hline Source Voltage & $415 \mathrm{~V}, 50 \mathrm{~Hz}$ \\
\hline Source Impedance & $0.1+\mathrm{j} 0.05 \Omega$ \\
\hline Load Impedance & $8+\mathrm{j} 12 \Omega$ \\
\hline DC-Link Capacitor & $1500 \mu \mathrm{F}$ \\
\hline VSI Filter Units & $\mathrm{R}-0.1 ; \mathrm{L}-5 \mathrm{mH}$ \\
\hline PI Controller Gains & $\mathrm{Kp}-0.8 ; \mathrm{K}-0.5$ \\
\hline
\end{tabular}

Case A: Integration of Co-Generation Scheme in Grid Connected System by Using Multi-Purpose STATCOM with Traditional PI based Advanced Current Controller

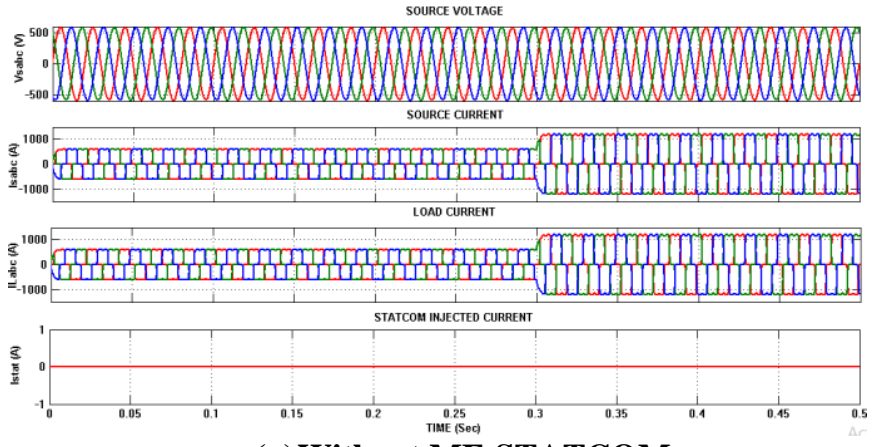

(a) Without MF-STATCOM
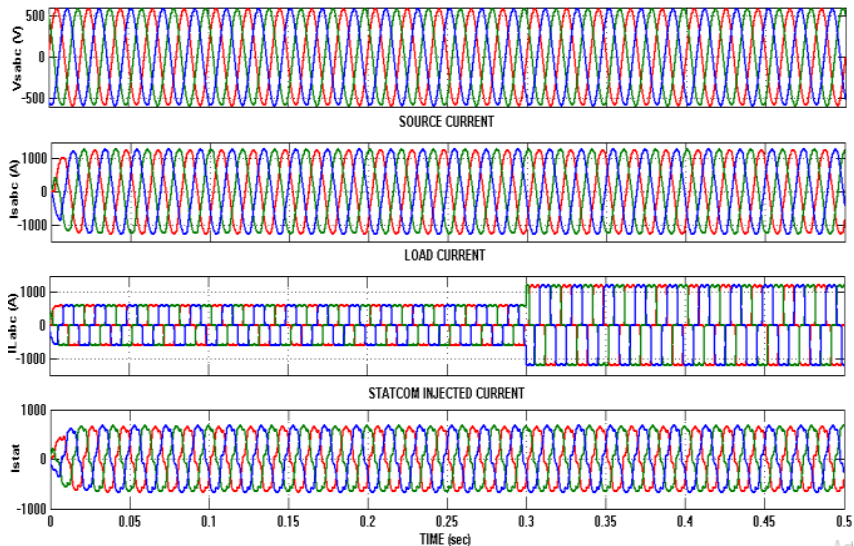

(b) With STATCOM Driving by Traditional PI Controller

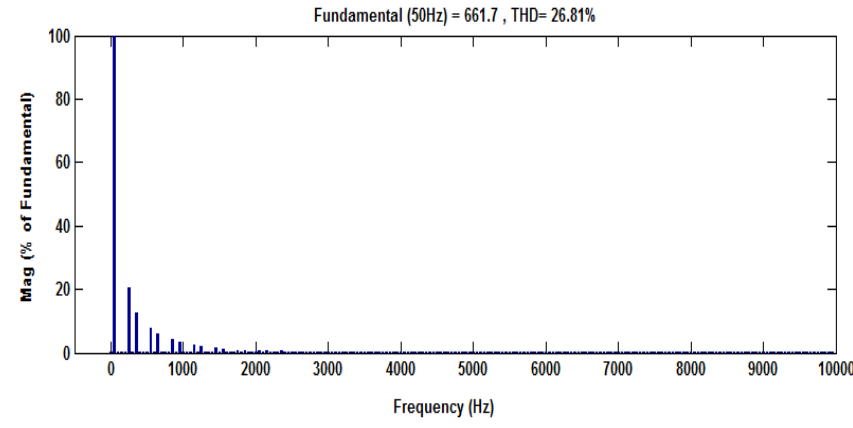

(c) THD of Source Current under Non-Presence of MF-STATCOM

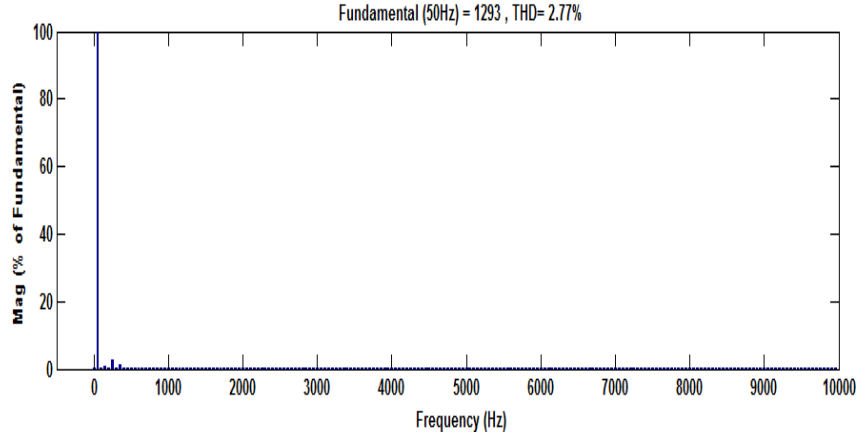

(d) THD of Source Current under with MF-STATCOM under Traditional PI Controller

Fig.8 Simulation Results of Proposed MF-STATCOM under Traditional PI Controller with CO-Generation Scheme

The simulation results of proposed MF-STATCOM are evaluated under traditional PI controller with CO-generation scheme as shown in Fig.8. Fig. 8(a) represents the source voltage, source current, load current and shunt injected current, respectively. The electric power grid is driving the dual non-linear loads, the primary load is operated continuously but the secondary load is switched $\mathrm{ON}$ at time $0.3 \mathrm{sec}$. Due to these sudden interruptions, source current is maintained as un-constant because, non-presence of MF-STATCOM and the load also maintained same. That's why the shunt-injected current maintained as zero and affects the PQ features at PCC of grid connected system. When the compensator is integrated at PCC level, the source current is maintained as constant and sinusoidal nature because the

STATCOM compensates the harmonic distortions and sudden interruptions coming from load. But the load current maintained as constant with respect to sudden interruptions, the source current is maintained constant, balanced and harmonic free response by injecting the in-phase currents of the STATCOM powered by Co-generation scheme. The THD of source current without MF-STATCOM is $26.81 \%$ as depicted in Fig. 8(c), THD of source current with MF-STATCOM is $2.77 \%$ as depicted in Fig. $8(d)$. The THD of source current under presence of MF-STATCOM is within IEEE-519 standards.

Case B: Integration of Co-Generation Scheme in Grid Connected System by Using Multi-Purpose STATCOM with Proposed Fuzzy-Logic based Advanced Current Controller 


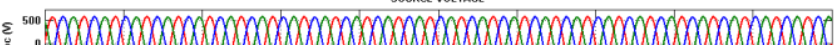

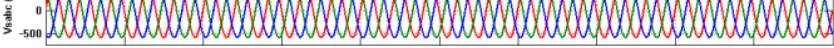

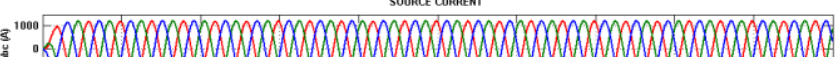

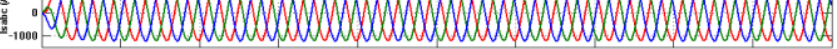
LOND CuRerert

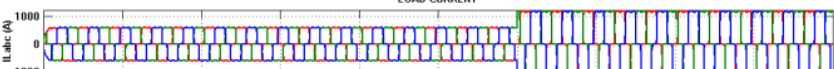

- 1000

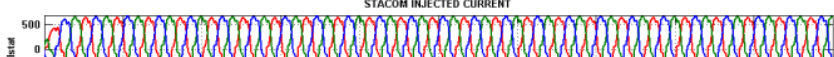

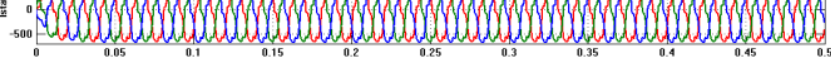

(a) With STATCOM Driving by Proposed Fuzzy-Logic Controller

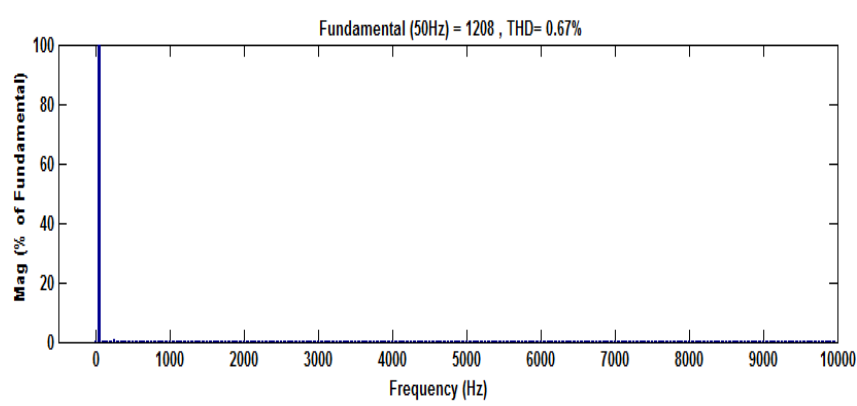

(b) THD of Source Current under with MF-STATCOM under Proposed Fuzzy-Logic Controller

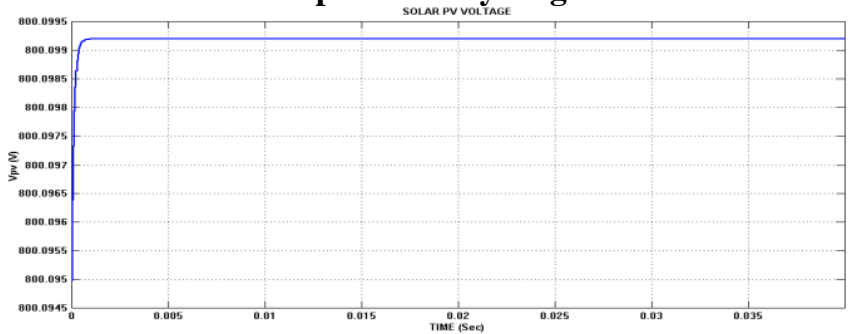

(c) Solar PV Output Voltage

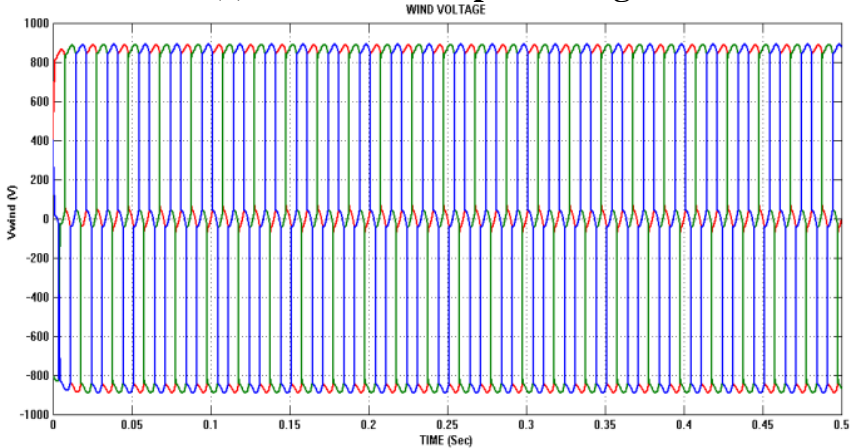

(d) Wind Energy Output Voltage

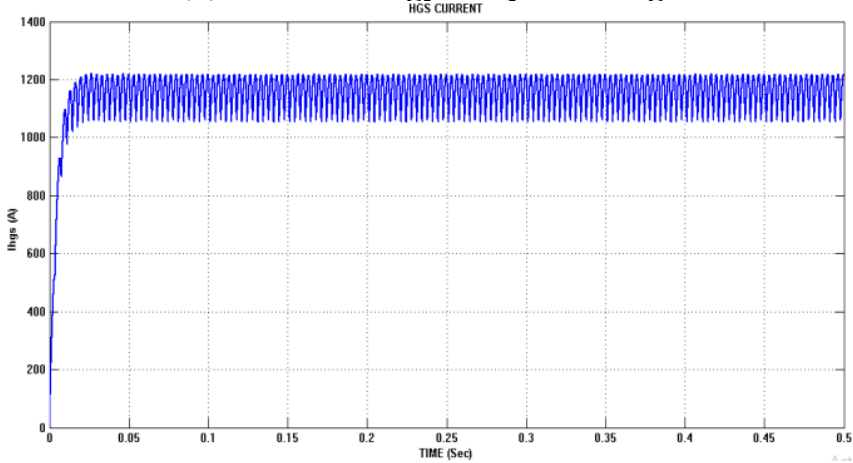

(e) Current of Co-generation Scheme

Fig.9 Simulation Results of Proposed MF-STATCOM under Proposed Fuzzy-Logic Controller with CO-Generation Scheme

The simulation results of proposed MF-STATCOM are evaluated under Proposed Fuzzy-Logic controller with CO-generation scheme as shown in Fig.9. In that, Fig. 9(a) represents the source voltage, source current, load current and shunt injected current, respectively. When the compensator is integrated at PCC level, the source current is maintained as constant and sinusoidal nature because the STATCOM compensates the harmonic distortions and sudden interruptions coming from load. But the load current maintained as constant with respect to sudden interruptions, the source current is maintained constant, balanced and harmonic free response by injecting the in-phase currents of the STATCOM powered by CO-generation scheme. The THD of source current with MF-STATCOM under Proposed Fuzzy-Logic controller is $0.67 \%$ as depicted in Fig. 9(b). The THD of source current under presence of MF-STATCOM with Proposed Fuzzy-Logic controller is well within IEEE-519 standards which enhances the PQ features in a grid connected CO-generation scheme. The Solar PV output voltage is attained with a value of $800 \mathrm{~V}$ and the output of Wind-Energy is attained with a value of $820 \mathrm{~V}$ and the current of co-generation scheme is nearly 1200A as depicted in Fig.9 (c), (d) and (e) respectively. Over the classical PI controller, the proposed Fuzzy Logic controller has better reduction of source current distortions, the THD is well within IEEE standard limitations for attaining improved PQ features in a MP-STATCOM as depicted in Table.4 and the graphical view is depicted in Fig.10.

Table.4 THD Comparison of Source Current under Several Control Functions

\begin{tabular}{|c|c|c|c|}
\hline THD (\%) & $\begin{array}{c}\text { Without } \\
\text { Compensator }\end{array}$ & $\begin{array}{c}\text { Classical PI } \\
\text { Controller }\end{array}$ & $\begin{array}{c}\text { Proposed } \\
\text { Fuzzy-Logic } \\
\text { Controller }\end{array}$ \\
\hline $\begin{array}{c}\text { Source } \\
\text { Current }\end{array}$ & $26.81 \%$ & $2.77 \%$ & $0.67 \%$ \\
\hline
\end{tabular}

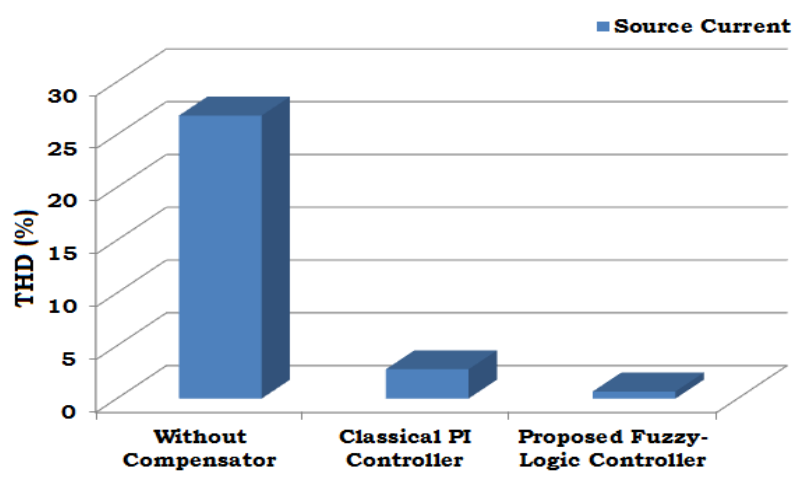

Fig.10 Graphical View of THD Analysis of Source Current under Traditional PI and Proposed Fuzzy-Logic Control Functions

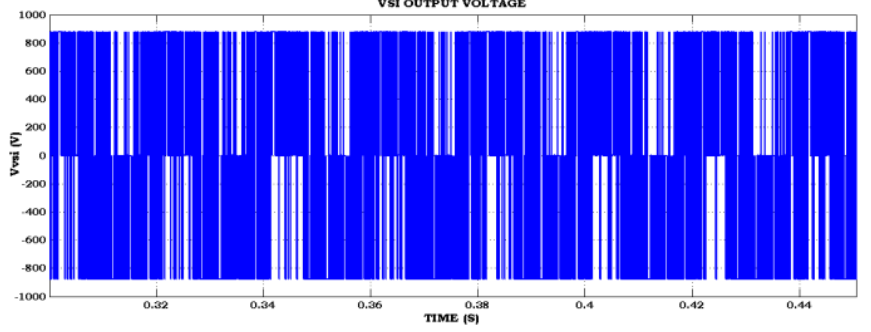

(a)Classical VSI Output Voltage

Published By:

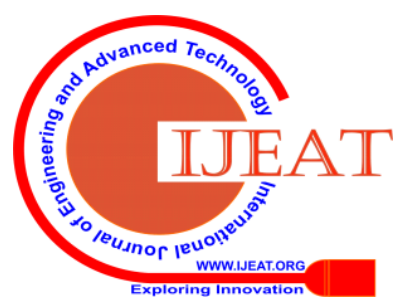




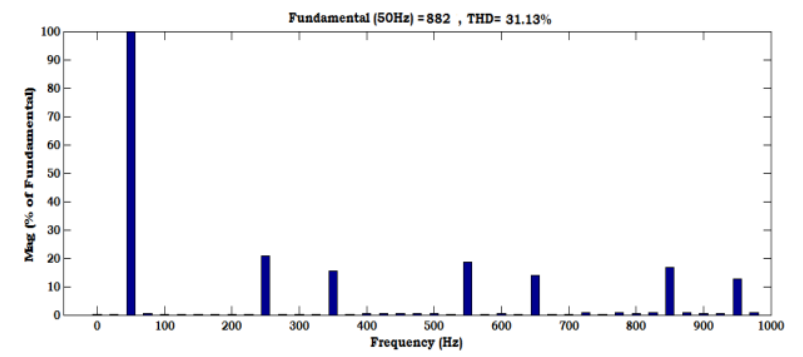

(b)THD of Classical VSI 3-Level Output Voltage

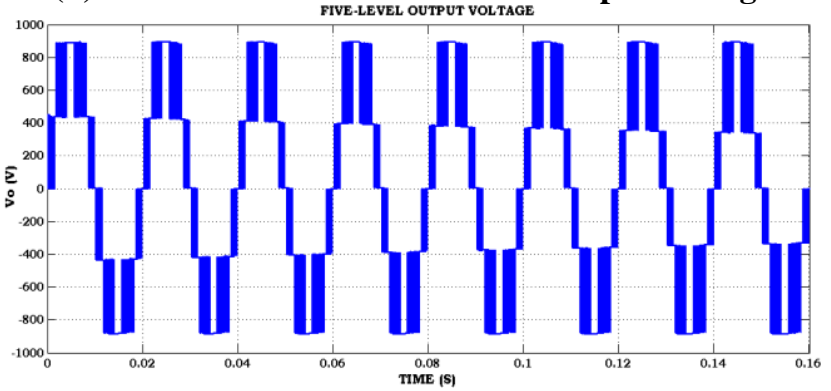

(c) Proposed 5-level DCMLI Output Voltage

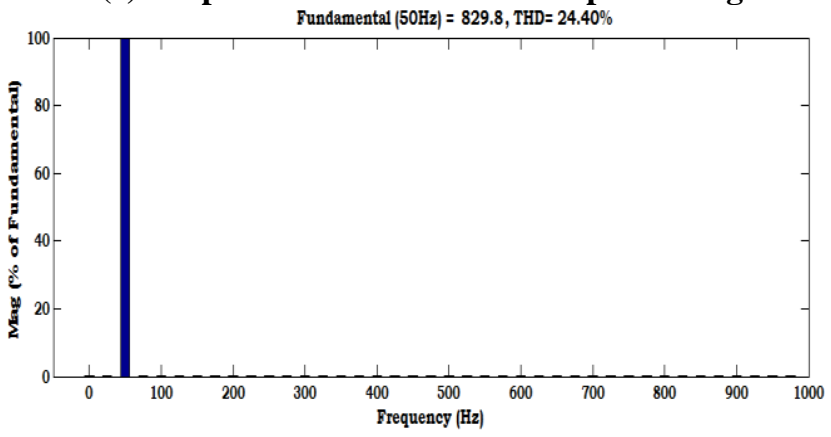

(e) THD of Proposed5-Level Output Voltage

Fig.11 Simulation Results of Proposed 5-Level DCMLI and Classical VSI Output Voltages

Table.5 THD Comparison of Source Current under Classical VSI and Proposed DCMLI Topologies

\begin{tabular}{|c|c|c|c|c|c|}
\hline & Without & \multicolumn{2}{|c|}{ Under Classical VSI } & \multicolumn{2}{|c|}{$\begin{array}{c}\text { Under Proposed } \\
\text { 5-Level DCMLI }\end{array}$} \\
\cline { 3 - 6 } $\begin{array}{c}\text { THD } \\
(\%)\end{array}$ & $\begin{array}{c}\text { Compens } \\
\text { ator }\end{array}$ & $\begin{array}{c}\text { Classical } \\
\text { PI } \\
\text { Controll } \\
\text { er }\end{array}$ & $\begin{array}{c}\text { Proposed } \\
\text { Fuzzy-Log } \\
\text { ic } \\
\text { Controller }\end{array}$ & $\begin{array}{c}\text { Classical PI } \\
\text { Controller }\end{array}$ & $\begin{array}{c}\text { Propo } \\
\text { sed } \\
\text { Fuzzy } \\
\text {-Logic } \\
\text { Contr } \\
\text { oller }\end{array}$ \\
\hline $\begin{array}{c}\text { Source } \\
\text { Current }\end{array}$ & $26.81 \%$ & $2.77 \%$ & $0.67 \%$ & $2.01 \%$ & $0.43 \%$ \\
\hline
\end{tabular}

Over the classical VSI-STATCOM, the proposed DCMLI-STATCOM has better reduction of source current distortions. The THD is well within IEEE standard limitations for attaining improved PQ features as depicted in Table.5.

\section{CONCLUSION}

The proposed DCMLI-STATCOM based advanced Fuzzy-Logic based current controller provides the optimal switching states under both PQ enhancement and DG operation. Under DG operation, the DCMLI-STATCOM doesn't require any additional VSI modules and control objectives for mitigating sudden interruptions coming from load. The proposed DCMLI-STATCOM has better features over the classical VSI-STATCOM and has carries low harmonic distortions, low switch stress, high efficiency, so on. The advanced control theory furnishes constant energy to the load under variations in SPV-Wind system by using attractive control function which reduces the additional controller, minimizes the cost, size and space requirement etc. The performance analysis of proposed DCMLI-STATCOM is evaluated under various working modes by using MATLAB/SIMULINK tool and results are conferred with appropriate comparisons. The harmonic spectrum's of source current under traditional PI and proposed Fuzzy controller, classical and proposed DC-MLI is getting well within IEEE-519/1992 standards limitations.

\section{REFERENCES}

1. J. H. Eto, K. H. LaCommare, "A quantitative assessment of utility reporting practices for reporting electric power distribution events", Proc. 2012 IEEE Power \& Energy Soc. General Meeting, Jul. 22-26, 2012.

2. Y.S. Kim, E.S. Kim, and S.I. Moon, "Frequency and voltage control strategy of standalone micro-grids with high penetration of intermitten renewable generation systems," IEEE Trans. Power Syst., vol. 31, no. 1, pp. 718-728, Jan. 2016.

3. Jose Mateus Rondina, "Technology Alternative for Enabling Distributed Generation" IEEE Latin America Transactions, Vol.14, no. 9, pp.4089 - 4096, 2016

4. J. He , Y. W. Li, F. Blaabjerg, and X. Wang , "Active harmonic filtering using current-controlled, grid-connected DG units with closed-loop power control," IEEE Trans. Power Electron., vol. 29, no. 2, pp. 642-653 , Feb. 2014

5. M. Bragard , N. Soltau, S. Thomas and R. W. D. Doncker, "The balance of renewable sources and user demands in grids: Power electronics for modular battery energy storage systems", IEEE Trans. Power Electron., vol. 25, no. 12, pp. 3049-3056, 2010

6. Muhamad MI, Marium N, Radzi MAM. The Effect of Power Quality to the Industries, In: 5th Student Conference on Research and Development SCOReD 2007: 1-4.

7. M. Farhoodnea, A. Mohamed, H. Shareef, "A comparative study on the performance of custom power devices for power quality improvement", Proc. IEEE Innovative Smart Grid Technologies, pp. 153-157, 2014

8. B. Singh, A. Chandra, K. Al. Haddad, "Power Quality Problems and Mitigation Technique," Hoboken, NJ, USA: Wiley Publishers, 2015.

9. C. Kumar, M.K. Mishra, "An improved hybrid DSTATCOM topology to compensate reactive and nonlinear loads", IEEE TRANS. IND. ELECTRON., vol. 61, no. 12, pp. 6517-6527, 2014.

10. Malinowski Mariusz, Gopalkumar K, Rodriguez Jose, Pe'rezMarcelo A. "A survey on cascaded multilevel inverters". IEE Trans Ind Electron 2010;57(7):2197-205.

11. Wu JC, Wu KD, Jou HL, Xiao ST. "Diode-clamped multi-level power converter with azero-sequence current loop for three-phase three-wire hybrid power filter". Elsevier J Electrical power systems Res 2011;81(2):263-70.

12. G. Satyanarayana, K. Lakshmi Ganesh, C. Narendra Kumar, M. Vijaya Krishna, "A critical evaluation of power quality features using Hybrid Multi-Filter Conditioner topology", Green Computing Communication and Conservation of Energy (ICGCE) 2013 International Conference on, pp. 731-736, 2013.

13. G. Sri Hari Priya, K. Lakshmi Ganesh, G. Satyanarayana, "Enhancement of Harmonics in a Grid Connected Advanced Three-Phase Multilevel Inverter with Hybrid Co-Generation Scheme", is Published in International Journal of Informative \& Futuristic Research (IJIFR), Vol-2 Issue-5, ISSN-2347-1697, p.p. 1201-1214, January, 2015

14. Sharad W. Mohod, Mohan V. Aware, "A STATCOM Control Scheme for Grid Connected Wind Energy System for Power Quality Improvement", IEEE SYSTEMS JOURNAL, VOL. 4, NO.3, SEPTEMBER 2010

15. S. R. Arya, B. Singh, R. Niwas, A. Chandra, K. Al-Haddad, "Power Quality Enhancement Using DSTATCOM in Distributed Power Generation System", IEEE Transactions on Industry Applications, vol. 52, no. 6, pp. 5203-5212, Nov.-Dec. 2016. 

Multilevel STATCOM

16. G. Satyanarayana, K.N.V. Prasad, G. Ranjith Kumar, K. Lakshmi Ganesh, "Improvement of power quality by using hybrid fuzzy controlled based IPQC at various load conditions", Energy Efficient Technologies for Sustainability (ICEETS) 2013 International Conference on, pp. 1243-1250, 2013.

17. G. Satyanarayana, K. Lakshmi Ganesh "Tuning a Robust Performance of Adaptive Fuzzy-PI Driven DSTATCOM for Non-Linear Process Applications" is Published in Springer LNCS Series-8947, ISSN-0302-9743, pp.523-533, July 2015.

18. S S N L Bhavani and L.Shanmukha Rao.,"Realization of Novel Multi-Feeder UPQC for Power Quality Enhancement Using Proposed Hybrid Fuzzy+PI Controller" IEEE International conference on Innovations in Power and Advanced Computing Technologies (i-PACT - 2019)VIT,Vellore,India,2019.

19. J Pavithra and L.Shanmukha Rao, "A Critical Evaluation of PV+Wind Co-Generation Scheme Based Static Compensator For PQ Improvement By Using Fuzzy-Logic Controller” IEEE International conference on Innovations in Power and Advanced Computing Technologies (i-PACT - 2019)VIT, Vellore,India,2019.

20. A.Navya, A.Panduranga Rao, L.Shanmukha Rao," Performance of Interline Unified Power Quality Conditioner (IUPQC) With PI, Fuzzy and ANFIS Controllers" International Journal of Engineering and Advanced Technology, Volume-9, Issue-3,Febraury 2020.

21. J Vara Lakshmi, L,Shanmukha Rao, "Power Quality Improvement Using Intelligent Fuzzy-VLLMS Based Shunt Active Filter", International Journal of Recent Technology and Engineering, Volume-8, Issue-6, March 2020..

22. T Ganesh, L.Shanmukha Rao, "Performance Assessment of Plug-in Electric Vehicle Supported DVR for Power-Quality Improvement and Energy Back-Up Strategy" International Journal of Recent Technology and Engineering, Volume-8, Issue-6, March 2020.

\section{AUTHORS PROFILE}

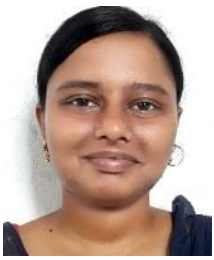

Sk.Shabana is an Under Graduate student studying IV B.Tech Electrical and Electronics Engineering from Kallam Haranadhareddy Institute of Engineering \& Technology, Guntur, A.P., India. She is one of the toppers in the college who got meritorious scholarship and won many prizes in the technical events held at intra and inter college level. Her research interests include Power Quality and Internet of Things (IoT).

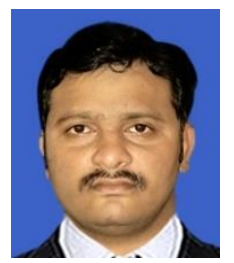

L ShanmukhaRao received Ph.D from Jawaharlal Nehru Technological University Hyderabad(JNTUH), Hyderabad,India in 2016 and M.Tech in Electrical Power Engineering from Jawaharlal Nehru Technological University (J.N.T.U), Hyderabad, A.P, India in 2006. He is currently Professor \& HOD of EEE at Kallam Haranadhareddy Institute of Engineering \& Technology, Guntur, A.P., India. His research interests include Power System Modeling and Control and renewable energy sources. He published more than 10 papers in international journals and conferences. 